\title{
Maritime Spatial Planning in the European Union on the Example of the Polish Part of the Baltic Sea
}

\author{
Agnieszka Bieda *(1), Tomasz Adamczyk $₫$ and Piotr Parzych \\ Department of Geomatics, AGH University of Science and Technology, 30-059 Cracow, Poland; \\ tomada@agh.edu.pl (T.A.); parzych@agh.edu.pl (P.P.) \\ * Correspondence: bieda@agh.edu.pl
}

Received: 8 February 2019; Accepted: 12 March 2019; Published: 17 March 2019

check for updates

\begin{abstract}
Spatial planning is an extremely powerful tool, which can be used for shaping the development of the largest spaces, including maritime space. In order to improve maritime management, the European Union decided to establish a framework in the form of a Directive to support planning processes in these areas. The result of the EU legislation will be land use plans, which will organize human activities in maritime areas in such a way as to meet environmental, economic and social objectives. The EU law applies to the Baltic Sea, Black Sea, Mediterranean Sea and the North-East Atlantic. However, since the internal regulations of individual EU countries differ from one another, the Polish part of the Baltic Sea was selected as an example. The conducted considerations include an analysis of the legal provisions that are to lead to the preparation of the above-mentioned plans. The research material includes both the provisions of the international and of the national laws. For the evaluation of the maritime spatial planning system, which is based on the above-mentioned research material, the SWOT/TOWS analysis has been used. This technique has been aimed at determining the directions of development of maritime spatial planning in Poland based on the current conditions of the spatial planning procedure for these areas as well as the future phenomena related to the implemented procedure for creating maritime area land use plans. It has been pointed out that maritime spatial planning should be carried out using the strengths of the current procedure and the external opportunities that would increase the importance of Polish maritime areas.
\end{abstract}

Keywords: spatial planning; maritime areas; Baltic Sea; SWOT/TOWS analysis

\section{Introduction}

The term spatial planning should be understood as all techniques aimed at shaping the space in a way that ensures its order [1] preceded by studies and analyses, based on scientific grounds, related to the location of objects in the adopted planning space [2]. The activities related to spatial planning are associated with future conditions of this space, and they are undertaken by the relevant public authorities on the basis of the current status of development. Planning procedures are launched in order to [3]:

- shape the space in such a way as to form a harmonious whole and take into account all the considerations and functional, socio-economic, environmental, cultural as well as compositional and aesthetic requirements in structured relationships;

- ensure socio-economic development, in which political, economic and social activities are integrated, maintaining natural balance and permanence of basic natural processes in order to guarantee a possibility to meet the basic needs of individual communities or citizens, of both the present generation and of the future generation; 
- implement actions, taking into account the objectified needs of the general public or local communities, associated with land development.

It should be remembered, however, that spatial planning procedures are not always carried out in a harmonious manner. It may be the case that different expectations as to the intended purpose of an area may lead to confrontational situations [4]. These so-called spatial conflicts usually arise when the parties thereto have conflicting interests with respect to the manner in which a given area is to be used [5].

As a result of the adoption of the Directive for establishing a framework for Maritime Spatial Planning by the European Parliament and the European Council, the problem of creating planning procedures has become a current issue; it would have resulted in land use plans for these areas. Since the European Community considered maritime areas to be extremely valuable, all the coastal countries of the European Union ought to create their own development plans for maritime areas before March 2021, and these plans should be developed within the framework of international cooperation [6]. Importantly, this cooperation should be carried out based on the rules of territorial governance [7]. These interactions ought to be understood as a set of formal and informal interactions that are allowed and conditioned by national spatial planning systems. In territorial management, both vertical relations (between policy levels) and horizontal ones (between policy sectors and between public/private operators) can be noticed.

Although the problem has already been tackled in scientific publications, i.e., [8-13], the European Union does not have much experience in this regard yet. The EU Member States are currently at various stages of creating procedures related to maritime spatial planning [14], and experience in transboundary approaches is growing through official processes and pilot programs [15]. Due to the fact that there mainly were pilot programs conducted, the aim of this study is to analyze the existing legal regulations and to assess the national procedures resulting therefrom.

The internal laws of the individual countries of the European Community differ from each other. It can be noticed, however, that maritime spatial planning borrows numerous methods from land planning [16]. Although each EU Member State has a unique spatial planning system for land areas, it is possible to identify groups of countries that have similar approaches [17], which is easily noticeable when analyzing the descriptions of spatial planning systems contained e.g., in [18-21]. That is the reason why this research paper narrows down the analysis of marine spatial planning to one country only. The Polish part of the Baltic Sea was selected as an example.

The research material includes both the provisions of the international and national laws. In addition, the statistical data on spatial planning procedures in areas of land and sea interaction have been analyzed. For the evaluation of the maritime spatial planning system, the SWOT/TOWS analysis has been used. The performed studies have been aimed at determining the directions of development of maritime spatial planning in Poland based on the current conditions of the spatial planning procedure for these areas as well as the future phenomena related to the implemented procedures for creating maritime area land use plans.

\section{Methodology of the Research}

A part of the research has involved an attempt to evaluate the Polish spatial planning system for marine areas using the SWOT/TOWS analysis, which is a popular heuristic technique applied to make decisions in strategic (long-term) planning [22]. The authors have decided that this method would be appropriate because the EU Compendium of Spatial Planning Systems and Policies clearly indicates that regional spatial planning is considered to be strategic planning [23], which aims to separate current management and operational activities from ground-breaking initiatives [22]. This very attempt to identify these innovative components of the Polish maritime spatial planning system is the most important element of the presented analyses.

Moreover, the use of the SWOT/TOWS analysis in this research is supported by certain assumptions contained in the subject literature stating that effective strategies are based on a good 
adjustment of internal resources to external opportunities [24]. Both of these components have their place in this analysis and thus they form the basis for the adoption of an appropriate development strategy [25].

An additional argument that confirms the relevance of using the SWOT/TOWS analyses for the evaluation of the Polish spatial planning system for maritime areas is the existence of similar research studies presented in the subject literature on the broadly understood spatial economy. In the past, it was used, e.g., to assess the future of the real estate cadaster [26], the development strategy of the maritime cadaster [27], the methods of managing harbor real property resources [28], the methods of legal protection of agricultural land [29], the directions of spatial development of cities [30] and the methods of valuation of land properties with mineral deposits [31].

The analysis performed for the purpose of this study, as any other SWOT/TOWS analysis, has been carried out in four steps [32]:

1. Determination and description of the factors that have either a positive or negative impact on the development of maritime areas.

2. Assigning significance to individual factors through the determination of weights.

3. Analysis of interrelations between the selected factors.

4. Selection of one of the four strategies.

\section{Materials Description}

The research material includes the provisions both of the international and the national laws as well as statistical data on spatial planning in the areas of land and sea interaction. According to the authors, their detailed description will give the reader a broader perspective and enable better reception and understanding of the conclusions being part of the SWOT/TOWS analysis.

\subsection{The Legal Definition of Maritime Areas}

A basic document in Maritime Law is the UN Convention on the Law of the Sea [33]. It was signed by 165 countries, the European Union and Palestine. Also, those countries which have not ratified it (e.g., the United States of America), or even not signed it (e.g., Turkey), recognize it as a codification of customary law of the sea and rely on its provisions [34]. In accordance with its provisions, the sovereignty of a coastal country extends beyond its land territory and internal waters. Any such country shall have the right to determine the territorial sea of the width not exceeding 12 nautical miles (i.e., 22,224 m). The belt of the territorial sea is measured out from the baselines, i.e., lines corresponding to the lowest water level, run along the coast, officially recognized by the coastal country. The outer boundary of the territorial sea is the line, every point of which is located at a distance equal to the width of the territorial sea to the nearest point of the baseline. The waters situated between the baseline of the territorial sea and the mainland are part of the internal waters of the country.

From the baselines, the boundaries of an exclusive economic zone are also determined, which is an area beyond the territorial sea, which is subject to the specific legal regime. It cannot extend beyond 200 nautical miles from the baselines. The coastal country has the sovereign rights there to explore, exploit, conserve and manage natural resources, marine waters, the seabed and its underground, as well as the jurisdiction with regard to the construction and use of artificial islands, engineering devices and structures, maritime scientific research and protection and conservation of the maritime environment. Beyond the exclusive economic zone, there are only high seas which are open to all countries, both coastal or landlocked. The cited definitions of maritime areas have been illustrated in Figure 1. 


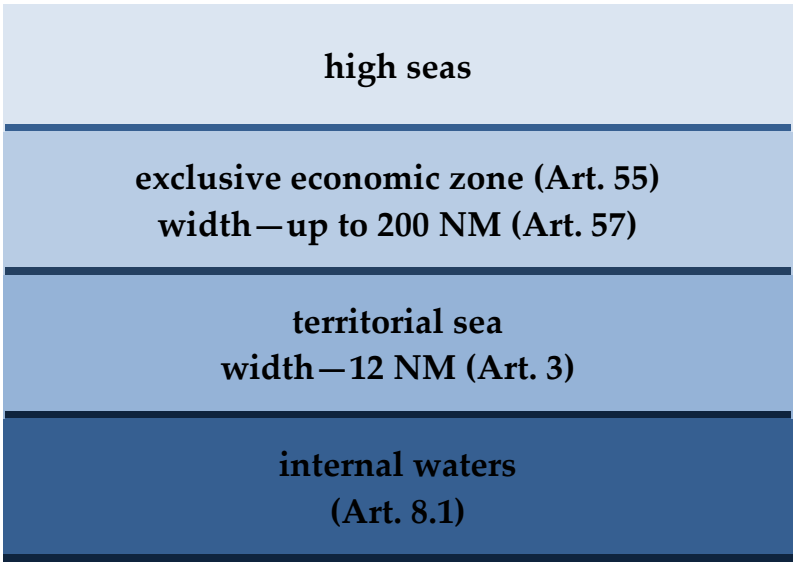

the boundary of the exclusive economic zone

boundary of the territorial sea (Art. 4)

Figure 1. Maritime areas according to the UN Convention on the Law of the Sea. Source: prepared by the author.

The European Union law defines coastal waters [35] and marine waters [36]. They are located within the territorial sea and the exclusive economic zone. Marine waters mean waters, seabed and subsoil located on the seaward side of the baseline, from which the extent of the territorial sea is measured, up to the farthest area of territorial waters, and extending up to the farthest area where a Member State has or exercises jurisdiction rights, in accordance with the UN Convention on the Law of the Sea. The coastal waters, on the other hand, are surface waters on the landward side of the line, every point of which is at a distance of one nautical mile on the seaward side from the nearest point of the baseline, which width of territorial waters is measured from, extending where appropriate, up to the outer limit of transitional waters (part of the surface waters in the vicinity of river mouths which are partly saline due to proximity to coastal waters, but which are substantially influenced by freshwater flows).

According to [37] maritime areas of the Republic of Poland include internal marine waters, territorial sea, the contiguous zone and the exclusive economic zone. The internal marine waters and the territorial sea are part of the Polish territory. The exclusive economic zone is located outside the territorial sea and is contiguous to that sea. Poland's supervision and jurisdiction over its maritime areas extends over the waters, the airspace above those waters, and the seabed of internal marine waters and territorial sea, as well as over the interior of the earth beneath them.

Between [33] and [37] there is a difference in the definition of internal marine waters. Under the Polish law, they are:

- part of Nowowarpieńskie Lake and a part of the Szczecin Lagoon, together with the Świna and Dziwna Rivers and Kamieński Lagoon, located east of the international border between the Polish Republic and the Federal Republic of Germany, and the Oder River between the Szczecin Lagoon and the port Szczecin waters,

- part of the Gulf of Gdańsk, enclosed with a baseline running from the point $54^{\circ} 37^{\prime} 36^{\prime \prime}$ north latitude, and $18^{\circ} 49^{\prime} 18^{\prime \prime}$ east longitude (on the Hel Peninsula) to the point at $54^{\circ} 22^{\prime} 12^{\prime \prime}$ north latitude and $19^{\circ} 21^{\prime} 00^{\prime \prime}$ east longitude (the Vistula Spit),

- part of the Vistula Lagoon, located south-west of the international border between the Republic of Poland and the Russian Federation on this Lagoon,

- port waters demarcated from the sea with a line connecting permanent port facilities which are the farthest out to the sea, forming an integral part of the harbor system,

- waters situated between the coastline and the baseline of the territorial sea.

Moreover, [37] introduces the coastal strip, or an area of land contiguous to the sea shore, running along the entire sea coast, which includes coastal technical belt and coastal protective belt. 
Technical belt is a zone of mutual direct impact of sea and land, designed to maintain the shore so that it complies with the safety requirements and environmental protection standards. It covers the area from the sea coast line towards the mainland with a width of 10 to $1000 \mathrm{~m}$, depending on the type of a shore, with the exception of land lying within the boundaries of ports and harbors [38].

The boundaries of the technical belt are determined as the lines connecting boundary points specified and set out in accordance with geodetic and cartographic law [39], taking into account:

- on the dune shores: the beach, the first dune embankment and a strip of land behind this embankment with a width from $20 \mathrm{~m}$ to $200 \mathrm{~m}$, counting from the landward foot of the dune embankment,

- on the cliff shores: the beach, the base of the cliff, cliff slope and a strip of land with a width of $10 \mathrm{~m}$ to $100 \mathrm{~m}$, below the upper edge of the slope,

- on the flat shores, without a dune embankment: a strip of land from the sea shore to the waterward foot of levees, or in the absence of levees-a strip of land with a width of $50 \mathrm{~m}$ to $1000 \mathrm{~m}$ from the sea shore,

- on the shores with hydro-technical structures forming the coastline, the area covering these structures together with a strip of land with a total width of $10 \mathrm{~m}$ or more, if it results from separate regulations.

Coastal protective belt covers an area in which human activities have a direct impact on the condition of the technical belt. It is contiguous to the landward boundary of the technical belt or sea harbor, of a width of $100 \mathrm{~m}$ to $2500 \mathrm{~m}$, and the lake Kopań, Bukowo and Jamno with the strip of land with a width of up to $200 \mathrm{~m}$ directly contiguous to them, counting from the boundaries of the record parcels which these lakes are located on, with the exception of the land lying within the boundaries of ports and harbors [38].

\subsection{EU Framework for Maritime Spatial Planning}

There are 46 countries on the European continent, 28 of which are already members of the European Union, and a further six enjoy an official EU candidate status. Only five countries of the Community countries have no access to the sea (Figure 2).

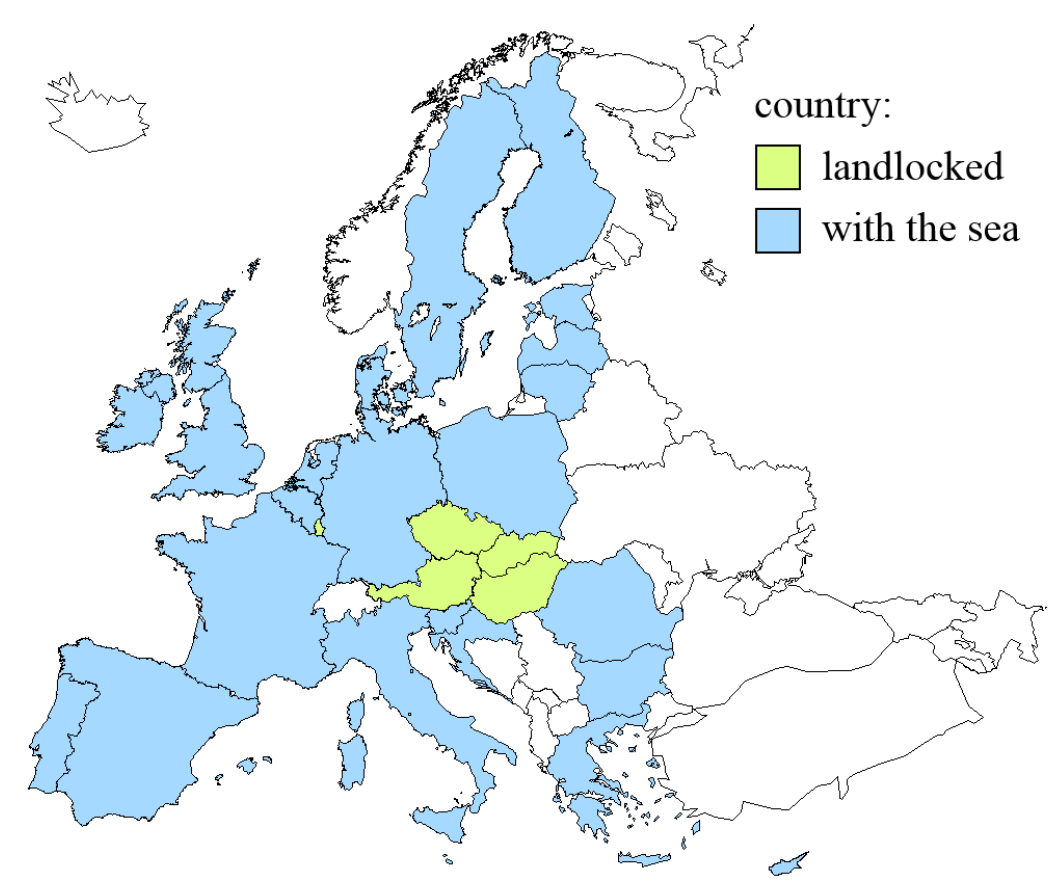

Figure 2. European Union countries with access to the sea. Source: prepared by the author. 
Europe has a highly complex and varied coastline. The islands represent approx. $7.5 \%$, and peninsulas approx. $25 \%$ of the continent surface area (own study based on [40]). It is surrounded by numerous seas and bays, which are parts of the Atlantic Ocean and the Arctic Ocean. Marine waters under the sovereignty and jurisdiction of Member States of the European Union include the following waters [36]:

- the Baltic Sea,

- the Black Sea (including the Sea of Azov),

- the Mediterranean Sea (including the Adriatic Sea, the Alboran Sea, the Balearic Sea, the Aegean Sea, the Icarian Sea, the Ionian Sea, the Ligurian Sea, the Tyrrhenian Sea),

- North-East Atlantic Ocean (i.e., the North Sea, including the Kattegat and the English Channel, the Celtic Sea, the Bay of Biscay and the Iberian Peninsula Coast, waters surrounding the Azores, Madeira and the Canary Islands, including the waters surrounding the Azores, Madeira and the Canary Islands).

Waters accessible to individual Member States of the European Union and the length of their coastline have been presented in Table 1.

Table 1. Coastline in the European Union countries. Source: own study based on [40].

\begin{tabular}{|c|c|c|}
\hline Country & Accessible Sea & The Coastline (km) \\
\hline Austria & landlocked & - \\
\hline Belgium & North Sea, Atlantic Ocean & 66.5 \\
\hline Bulgaria & Black Sea & 354 \\
\hline Croatia & Mediterranean Sea & 5835 \\
\hline Cyprus & Mediterranean Sea & 648 \\
\hline Czech Republic & landlocked & - \\
\hline Denmark & Baltic Sea, North Sea, Atlantic Ocean & 7314 \\
\hline Estonia & Baltic Sea & 3794 \\
\hline Finland & Baltic Sea & 1250 \\
\hline France & North Sea, Mediterranean Sea, Atlantic Ocean & $3427^{*}$ \\
\hline Germany & Baltic Sea, North Sea, Atlantic Ocean & 2389 \\
\hline Greece & Mediterranean Sea & 13,676 \\
\hline Hungary & landlocked & - \\
\hline Ireland & Atlantic Ocean & 1448 \\
\hline Italy & Mediterranean Sea & 7600 \\
\hline Latvia & Baltic Sea & 498 \\
\hline Lithuania & Baltic Sea & 90 \\
\hline Luxemburg & landlocked & - \\
\hline Malta & Mediterranean Sea & 253 \\
\hline Netherlands & North Sea, Atlantic Ocean & 451 \\
\hline Poland & Baltic Sea & 440 \\
\hline Portugal & Atlantic Ocean & 1793 \\
\hline Romania & Black Sea & 225 \\
\hline Slovakia & landlocked & - \\
\hline Slovenia & Mediterranean Sea & 46.6 \\
\hline Spain & Mediterranean Sea, Atlantic Ocean & 4964 \\
\hline Sweden & Baltic Sea, North Sea, Atlantic Ocean & 3218 \\
\hline United Kingdom & North Sea, Atlantic Ocean & 12,429 \\
\hline
\end{tabular}

The European Union works for the constant development of the European continent, which is based, inter alia, on sustainable economic growth, high level of protection and quality improvement of the natural environment, as well as supporting scientific and technical progress [41]. Therefore, in order to ensure sustainable growth in the maritime economy, sustainable development of maritime areas and sustainable use of maritime resources, the Directive establishing a framework for Maritime Spatial Planning was adopted in 2014 [42]. 
It provides for the integrated maritime policy to enable the implementation of maritime spatial planning for EU maritime areas, taking into account:

- interaction between land and sea,

- environmental, economic, social and security aspects,

- coherence between maritime spatial planning and the resulting land use plan or plans, and other processes, such as Integrated Coastal Zone Management or equivalent formal or informal action,

- involvement of the interested parties,

- use of best available data,

- cross-border cooperation between Member States,

- cross-border cooperation with third countries.

As a result of the policy of maritime spatial planning, no later than 31 March 2021, plans should be drawn up for maritime spatial planning, which shall take into account:

- areas of aquaculture,

- fisheries,

- engineering devices and infrastructure for exploration, exploitation and extraction of oil, gas and other energy sources, minerals and aggregate, as well as the production of energy from renewable sources,

- sea shipping routes and traffic routes,

- military areas,

- nature and species conservation areas and protected areas,

- areas of raw material extraction,

- research studies,

- the course of submarine cables and pipelines,

- tourism,

- underwater cultural heritage.

The Directive applies neither to coastal waters or parts thereof, subjected to spatial planning of urban and rural areas, provided that this will be specified in spatial planning of maritime areas, nor to land covered by the planning.

Maritime spatial planning should have been implemented and established by each Member State until 18 September 2016, but the landlocked countries were not obliged to transpose and apply the Directive.

Preparatory activities for maritime spatial planning of the European Union have been performed as part of the projects (Figure 3):

- MASPNOSE, conducted in the North Sea in 2010-2012,

- Plan Bothnia, conducted in the Gulf of Bothnia of the Baltic Sea in 2010-2012,

- BaltSeaPlan, implemented under the Baltic Sea Region Program “Introducing Maritime Spatial Planning in the Baltic Sea", in 2009-2012,

- $\quad$ TPEA, for cross-border maritime spatial planning in European waters of the Atlantic, including the Celtic Sea and the Bay of Biscay, conducted in 2012-2014,

- $\quad$ ADRIPLAN, conducted in the Adriatic Sea and the Ionian Sea in the years 2013-2015. 


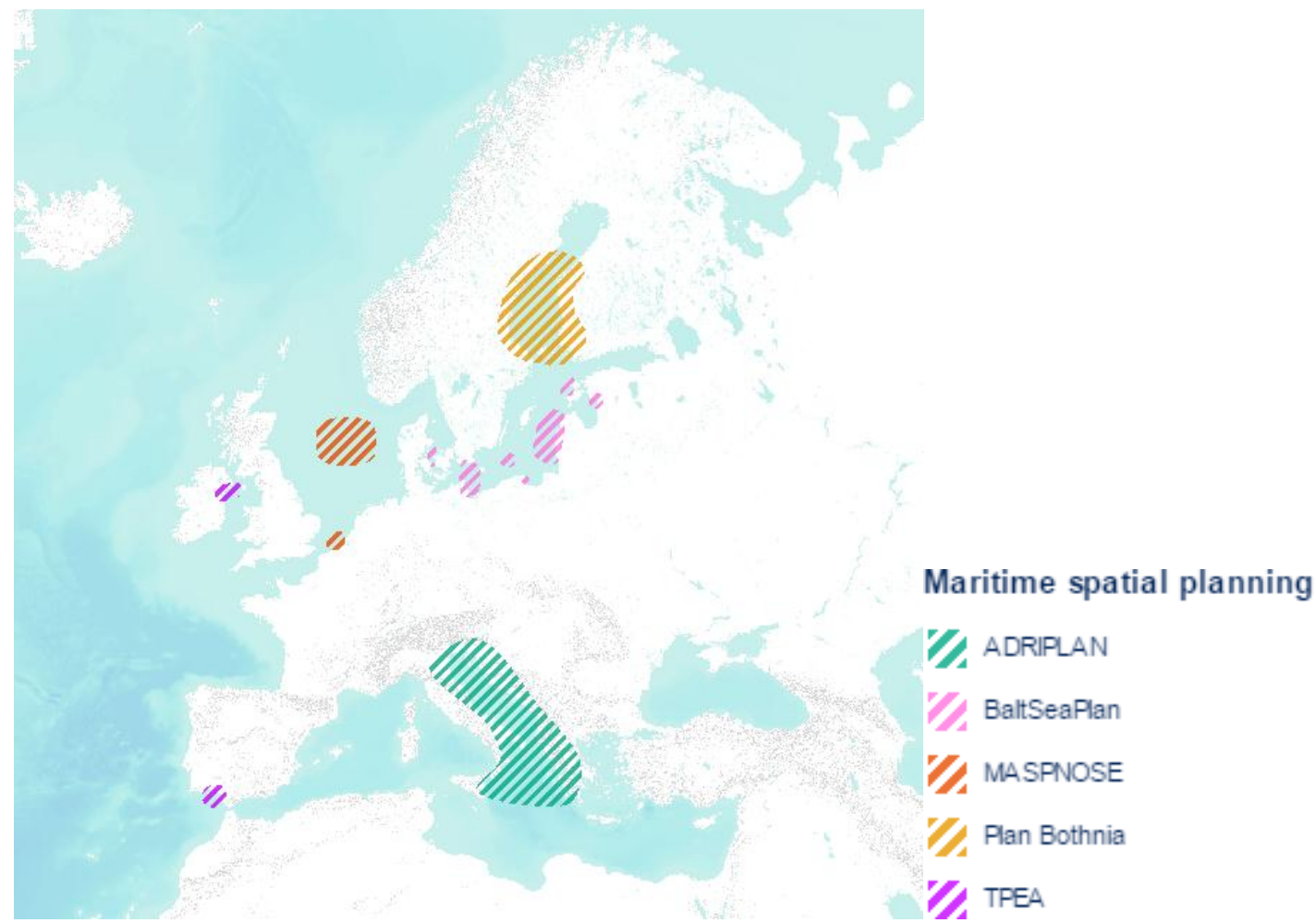

Figure 3. Maritime spatial planning in Europe. Source: [43].

Prior to that, from April 2006 until April 2008, the planning procedures were checked in the PlanCoast project. Its goal was to develop tools and possibilities to effectively integrate spatial planning in coastal zones and maritime areas of the Baltic Sea, the Adriatic Sea and the Black Sea.

\subsection{Spatial Planning in the Area of the Polish Part of the Baltic Sea}

European Union Member States may include regulations or mechanisms into the spatial plans of maritime areas, or develop these plans based on the existing national strategies. These regulations or mechanisms must meet two conditions:

- they have been or will be established prior to their entry into force [42],

- their content is in accordance with the requirements [42].

As part of BaltSeaPlan, on the Polish coast the following were created: a pilot project of the land use plan for the Polish part of the Central Shoal; a project of assessing the environmental impact of the pilot project of the land use plan for the western part of the Gulf of Gdansk; and a pilot project of the land use plan for the Pomeranian Bay. PlanCoast led to the creation of a pilot project of the land use plan for the western part of the Gulf of Gdańsk.

Over the Polish part of the Baltic Sea, planning works are being carried out all the time, at different levels of detail. Their goal is to create planning studies for land and maritime areas (Table 2).

Planning documents include development strategies as well as programs and program documents, created as part of the so-called development policy (Table 3), i.e., a group of interrelated activities, undertaken and implemented in order to ensure sustainable and balanced development of country, socio-economic, regional and spatial coherence, higher competitiveness of the economy and creating new workplaces on a national, regional or local level [45]. 
Table 2. Planning studies for land areas. Source: own study based on [44].

\begin{tabular}{|c|c|c|}
\hline Level & Study & Description \\
\hline \multirow[b]{2}{*}{ Country } & $\begin{array}{l}\text { National Spatial } \\
\text { Development Concept }\end{array}$ & $\begin{array}{l}\text { Adopted by a resolution of the Council of Ministers. It defines the } \\
\text { considerations, objectives and directions of sustainable development of } \\
\text { the country and the activities necessary to achieve it. }\end{array}$ \\
\hline & $\begin{array}{l}\text { Programs for the } \\
\text { implementation of public } \\
\text { purpose investments of } \\
\text { national importance }\end{array}$ & $\begin{array}{l}\text { Prepared by the Ministers and central government bodies in terms of } \\
\text { their subject matter jurisdiction. It takes into account the same } \\
\text { objectives and directions as the National Spatial Development Concept. } \\
\text { Adopted under the Council of Ministers resolution. }\end{array}$ \\
\hline Province & $\begin{array}{l}\text { Land use plan for the } \\
\text { province }\end{array}$ & $\begin{array}{l}\text { Adopted by the council of the province, following the findings of the } \\
\text { National Spatial Development Concept. }\end{array}$ \\
\hline \multirow{3}{*}{ Municipality } & $\begin{array}{l}\text { Study of conditions and } \\
\text { directions of spatial } \\
\text { development }\end{array}$ & $\begin{array}{l}\text { The resolution of the Municipal Council to determine the spatial policy } \\
\text { of the municipality, including local zoning rules. It is prepared for the } \\
\text { whole of the municipality. This is a document of the local law. } \\
\text { Its findings are binding on the creation of a local development plan. }\end{array}$ \\
\hline & Local land use plan & $\begin{array}{l}\text { The resolution of the Municipal Council to determine land use, } \\
\text { including for a public purpose investment, and to identify ways of their } \\
\text { management and development. It does not have to cover the whole of } \\
\text { the municipality. It is an act of the local law. On its basis, administrative } \\
\text { decisions are issued. }\end{array}$ \\
\hline & $\begin{array}{l}\text { Spatial planning } \\
\text { permission }\end{array}$ & $\begin{array}{l}\text { In the absence of a local plan, land use changes such as construction } \\
\text { work or the execution of other building works, as well as the change of } \\
\text { use of a building structure or a part thereof requires the settlement of } \\
\text { a zoning decision. Such a decision shall be made by a mayor or } \\
\text { president of the city at the request of the person concerned. The public } \\
\text { purpose investment is localized at the request of the investor, by way of } \\
\text { a decision on the location of public purpose investment. Depending on } \\
\text { the importance of an investment, it can be issued by a public authority } \\
\text { at municipal or provincial levels. }\end{array}$ \\
\hline
\end{tabular}

Table 3. Documents created as part of the development policy. Source: own study based on [45].

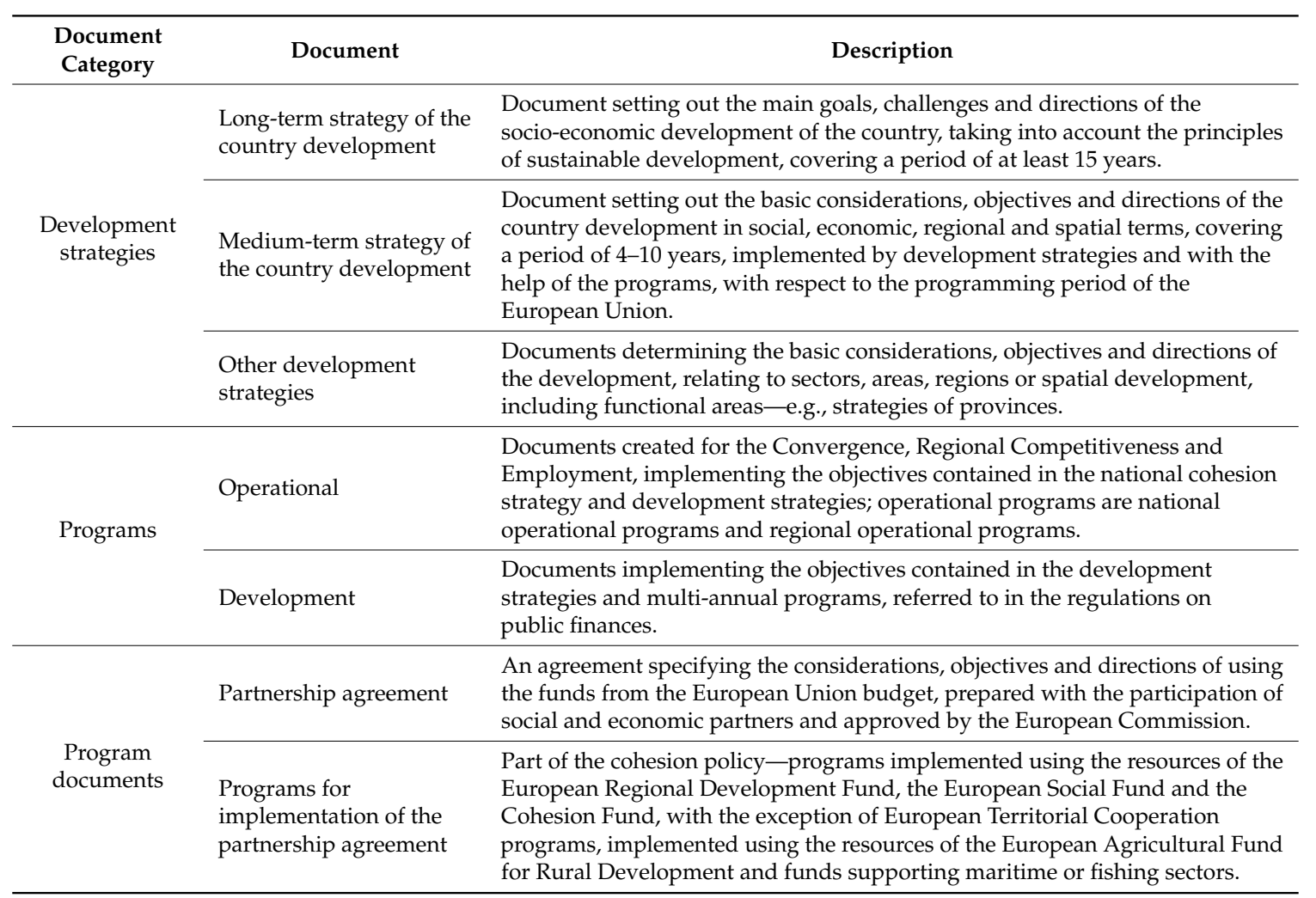


Several international organizations are also involved in the spatial planning in the Baltic Sea region (Table 4).

Although there is no obligation to take the studies prepared by them into account for maritime spatial planning, a joint Working Group HELCOM (The Baltic Marine Environment Protection Commission - the international organization proclaimed by the so-called Helsinki Convention of 1974 as its executive body, whose task is to monitor and protect the natural environment of the Baltic Sea) and VASAB for maritime spatial planning, have proposed to create the so-called Road Map for Maritime Spatial Planning of the Areas of the Baltic Sea 2013-2020. It was adopted by the HELCOM Ministerial Conference in 2013 and received support in the Declaration of VASAB Ministerial Conference in September 2014. From its records it was evident that maritime spatial planning should have been regulated in all Baltic States before 2017. Before the end of 2020, national maritime land use plans are to be drawn up. The plans have to be consistent across borders [46].

Table 4. International organizations involved in the spatial planning of the Baltic Sea. Source: own study based [47-50].

\begin{tabular}{cl}
\hline Organization & \multicolumn{1}{c}{ Description } \\
\hline COMMIN & $\begin{array}{l}\text { COMmon MINdscapes—-sets the basis for spatial policy around the Baltic Sea. It consists of } \\
\text { 28 partners from 11 countries. These are state organizations, universities and private companies. }\end{array}$ \\
\hline \multirow{2}{*}{ ESPON } & $\begin{array}{l}\text { European Spatial Planning Observation Network Project-a European network of spatial } \\
\text { planning observatories, research program implemented under the Community initiative } \\
\text { INTERREG III, whose goal is to conduct analyses of changes to the spatial structure in Europe. }\end{array}$ \\
\hline \multirow{2}{*}{ ISOCARP } & $\begin{array}{l}\text { International Society of City and Regional Planners- established in 1965, an association of } \\
\text { recognized and highly qualified planners from more than 80 countries around the world. In 2009, } \\
\text { in Szczecin, workshop was held, aimed at creating a development strategy for the metropolitan } \\
\text { area of Szczecin, as for the most important city of the Pomeranian Euroregion (including Polish, } \\
\text { Swedish and German lands). }\end{array}$ \\
\hline VASAB & $\begin{array}{l}\text { Vision and Strategies around the Baltic Sea-multilateral cooperation of all 11 countries located in } \\
\text { the Baltic Sea region, in terms of planning and zoning. VASAB highest decision-making body is } \\
\text { the Ministerial Conference. In 1996, in Stockholm, "Recommendations for Spatial Planning of the } \\
\text { Coastal Zone in the BSR" was introduced. Since then, coastal areas and islands are one of the six } \\
\text { pillars of the spatial concepts developed by VASAB. }\end{array}$ \\
\hline &
\end{tabular}

\subsection{The Land Use Plan for Maritime Areas}

The basic document for spatial planning in Poland, i.e., the Act on Spatial Planning and Land Development of 2003 [44] says that the intended zoning of land, the location of public investments, the land-use and land development conditions, in relation to maritime areas, are determined by the Maritime Areas Act of the Republic of Poland and Maritime Administration [37].

The land use plan for marine internal waters, territorial sea and exclusive economic zone, by regulation, may be adopted by a minister responsible for maritime affairs and minister responsible for regional development, in consultation with the ministers responsible for the matters of the environment, water management, culture and national heritage protection, agriculture, fisheries, transport, internal affairs, and with the Minister of National Defence.

The minister decides on $[37,51]$ :

- intended use of the areas of internal marine waters, territorial sea and exclusive economic zone, in particular for the needs of:

maritime transport,

sports, tourism and recreation,

marine breeding and cultivation,

fishing,

construction of artificial islands, structures and engineering devices,

technical infrastructure, 
ensuring safety and public order,

- prohibitions or restrictions on the use of maritime areas, taking into account the requirements of environmental protection, in particular in the fields of scientific research, shipping, fishing, construction and use of artificial islands, structures, engineering devices and technical infrastructure, bathing and motorboat sports,

- the location of public investments,

- directions of the development of transport and technical infrastructure, also shipping, including boundaries of the zones closed to shipping and fishing, continuously and periodically,

- areas and conditions of environmental and cultural heritage protection, including protected waters in spas, permanently and temporarily protected districts regarding fisheries, areas with mineral deposits, documented or confirmed by preliminary studies and information contained in geological maps, and mining areas covered by concessions.

- The plan should take into account [51]:

- objectives and directions set out in development strategies and programs created to implement development policy,

- objectives and directions of sustainable development of the country, as defined in the concept of spatial development of the country,

- objectives, principles and directions of spatial policy of provinces, as defined in spatial planning of provinces,

- public purpose investments of national importance, included in the programs of government tasks used to implement public purpose investments of national importance,

- settlements of local land use plans of appropriate coastal municipalities,

- settlements of studies of conditions and directions of spatial development of appropriate coastal municipalities,

- settlements of the plans for the protection of national parks, nature reserves and natural landscape parks, as well as conservation plans for Natura 2000 sites, and other forms of nature protection,

- valid permits for the construction and use of artificial islands, structures and engineering devices in Polish maritime areas, and the laying and maintenance of submarine cables and pipelines in the marine internal waters and the territorial sea, issued before the plan entry into force,

- concessions issued under [52], for the exploration or prospecting of mineral deposits, hydrocarbon from deposits, underground carbon dioxide storage, extraction of minerals and hydrocarbons from deposits, underground non-reservoir storage of substances, waste and carbon dioxide, as far as they concern maritime areas covered by the plan.

Due to the fact that it is prohibited to erect and use wind power stations in internal marine waters and territorial sea, the plan must take this into account.

The draft plan is drawn up by the managing director of a maritime office, competent for the area covered by the plan. In the territory of the Republic of Poland, there are three maritime offices (Figure 4): in Gdynia, Słupsk and Szczecin.

The environmental impact assessment including statement of reasons with a description of the existing condition, the characteristics of considerations regarding zoning the area covered by the plan and indicating the grounds for the issuance of a planning decision contained in the plan settlements, are prepared for the draft land use plan.

The draft plan is prepared using current planning materials and source data. The former are understood as documents and studies prepared for the needs of the plan, study, analysis, assessments, adopted studies and decisions issued by the competent authorities for the contiguous area of land. The source data, on the other hand, is information about a specific area, having an impact on its future use, in particular regarding the existing shipping routes, protected nature areas, places of prospecting, exploration, or extraction of mineral deposits, location of technical infrastructure, shipwrecks, storage of excavated material, military areas, areas of cultural heritage, live fish stocks and fishing activity, 
tourism, existing and planned land use for the land and maritime areas contiguous to this area, ecological risk models, as well as maps, documents and studies referring to the area covered by the plan, drawn up on the basis of separate regulations.

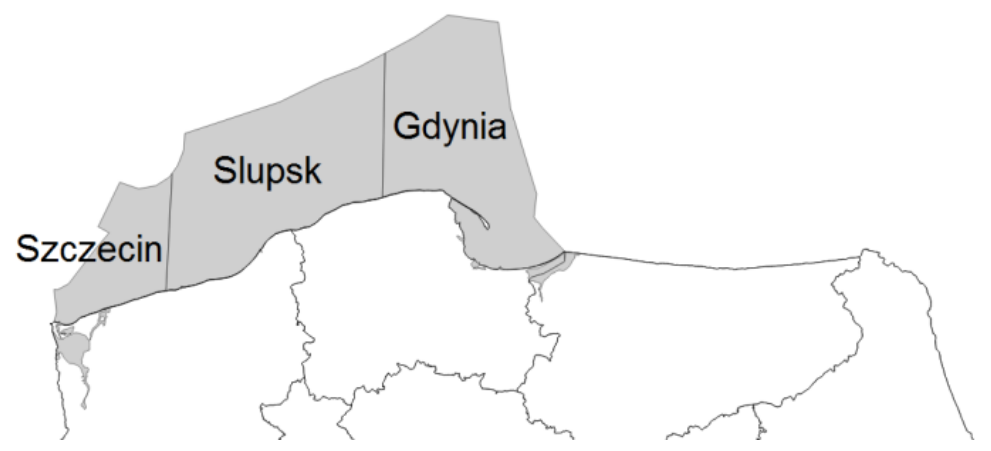

Figure 4. Territorial scope of the Maritime Offices. Source: prepared by the author based on State Register of Borders.

Poland does not have a spatial plan for maritime areas. The works on the plan are conducted in the following stages [46]:

- study of conditions of spatial development,

- development of the draft plan,

- conducting cross-border consultations.

For this purpose, already in 2013, an agreement was signed between the managing directors of the Maritime Offices in Szczecin, Słupsk and Gdynia, on cooperation in preparing the study for the Polish maritime areas and the spatial development plan for the Polish maritime areas. According to its content, one single coherent draft spatial development plan is prepared for the Polish maritime areas.

After the adoption of the plan, it will be necessary to perform additional studies, resulting from the indications contained in the strategic plan, and to prepare more detailed plans for the areas specified therein, i.e., lagoons, harbor areas and selected water bodies.

The study of conditions of spatial development of the Polish maritime areas, together with the spatial analyses, were completed earlier than expected, i.e., in November 2014. It covers maritime areas, in part referring to the exclusive economic zone and the territorial sea of the Republic of Poland, as well as the belt of marine waters located between the baseline of the territorial sea and the boundaries of the record parcels of the land area, contiguous to the marine waters, including internal marine waters of the Gulf of Gdansk. It consists of two parts: the text and the graphic part, which includes 23 maps. It is an inventory and assessment of the condition of maritime areas, it is of informative nature only. The study was drawn up in order to collect and analyze data for the purpose of preparing the land use plan for the selected part of the Polish maritime areas. It is not binding on local authorities involved in drawing up local plans for land areas.

The information contained herein covers the following issues [53]:

- oceanographic, i.e., physical and chemical parameters, depth, currents, waves, winds, storms intensity, water levels, etc.,

- natural, i.e., boundaries of the areas protected by law, occurrence of habitats and rare species of flora and fauna, photic zones, spawning-grounds and feeding sites for industrial fish.

- hydromorphological, i.e., dynamics of the shoreline,

- geological, including the types of deposits and mineral resources.

The study also presents the analyses of land areas contiguous to the maritime areas contained herein, the existing methods and potential future uses and ways of management of maritime areas, including for the purposes of renewable energy, mining and mariculture. 
The works on a draft of the land use plan of Polish maritime areas started back in July 2016. Over the course of the second project stage, comments and conclusions of the draft plan were collected and the planning materials, necessary for developing the preliminary draft plan, were obtained. In 2017, national and international consultative meetings and industry consultations were held. As a result, in June 2018 a draft of land use plan for Polish maritime areas was made publicly available. Nowadays, the next version of the draft plan is underway and it takes into account the opinions and comments submitted up to the date. As per the project plan, in October 2019 a draft plan is to be submitted to the minister of maritime economy for acceptance and adoption of the plan in a way of a regulation.

\subsection{National Spatial Development Concept}

The effective concept of spatial development of the country is the resolution of the Council of Ministers of 13 December 2011 [54]. It contains in particular [44]:

- basic elements of the national settlement network,

- requirements of environmental protection and monuments, including the protected areas,

- distribution of social infrastructure of international and national significance,

- distribution of objects of technical infrastructure and transport, strategic water resources and water management facilities of international and national significance,

- functional areas of supra-regional significance.

The latter ones were distinguished based on a dominant problem of spatial nature, whose range of influence extends beyond the local, and even regional, sphere. They require a special approach in terms of spatial development policy of the country. The current concept of spatial development of the country identifies (Figure 5):

- the coastal zone,

- the Polish exclusive economic zone,

- the mountain areas,

- Żuławy region,

- Soil protection areas for the purposes of agricultural production,

- closed areas,

- $\quad$ areas at risk of flooding in the river basins.

For maritime spatial planning, the coastal zone (purple) and the Polish exclusive economic zone (orange) are, of course, the most important.

Pursuant to the provisions of the concept, the state administration authorities and local self-government bodies at all levels, are responsible for spatial planning of the coastal areas. To lay the grounds for the spatial integration of the maritime areas and to use it optimally, the following should be developed:

- a study of spatial development of coastal areas,

- a draft development plan for maritime areas.

A specially appointed team is to be held responsible for the preparation of the study. The study is to include settlements binding for the maritime administration, provincial governments, and through the spatial development plan of the province, also coastal municipalities while creating their respective strategies, plans and programs.

The plan is to be drawn up with specifying at the same time the procedures guaranteeing the correlation between spatial development plans of the maritime area and of the land part of the coastal zone. Preparation of the development plans for maritime areas and development plans for land areas at the interface with maritime areas, should be subjected to the mutual consultation procedures between the authorities responsible for their preparation. In order to draw up plans for maritime 
spatial development, it is necessary to define expectations with respect to the coastal zone, resulting from the needs of the land areas.

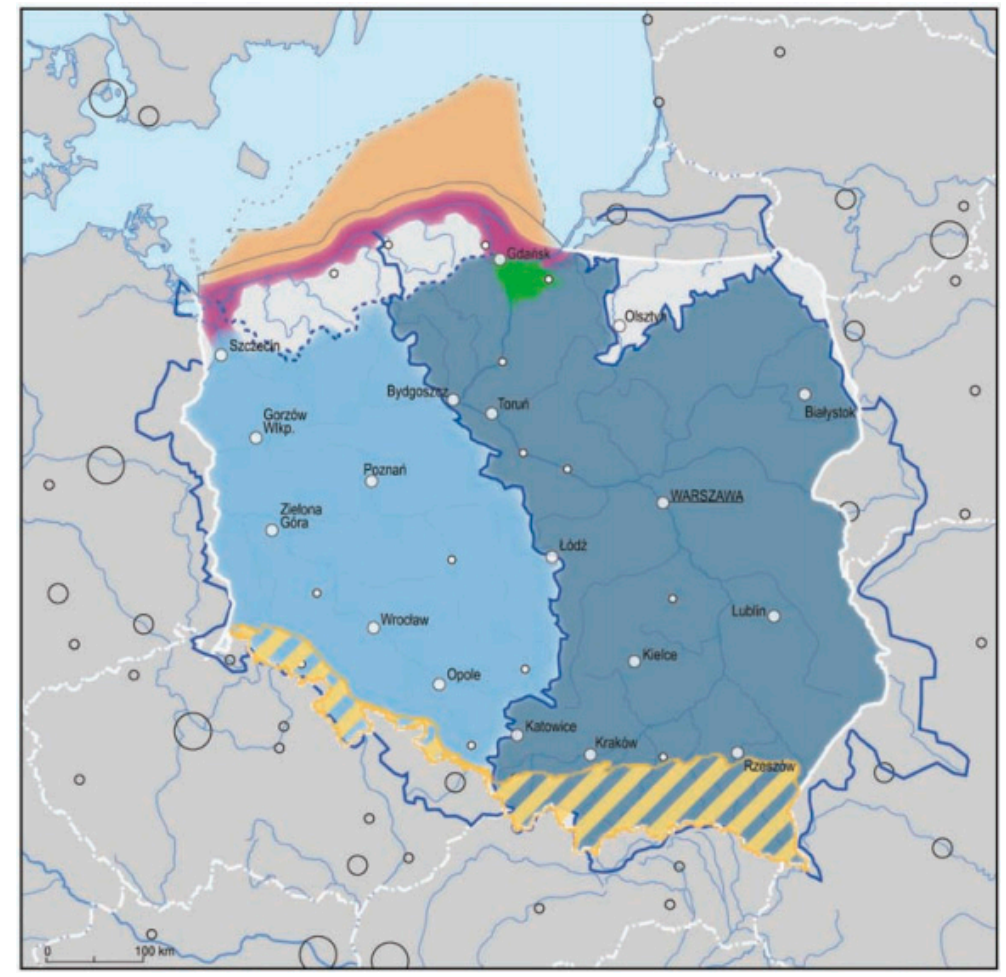

Figure 5. Functional areas of supra-regional significance. Source: [54].

Distinguishing the Polish exclusive economic zone as an area of supra-regional significance is supported by the fact that this is an area which:

- creates a compact spatial arrangement, consisting of functionally related waters, characterized by common considerations as well as predicted, uniform development objectives,

- is subjected to customary international law requiring multilateral cooperation,

- is not private property, and the right to dispose of the space by proprietors is limited,

- is sensitive to imbalance,

- has a small group of interested parties,

- ceased to be a good which is relatively abundant.

The functional area plan should be part of the land use plan for maritime areas, drawn up for the coordination of the defined investment locations and their protective zones, the zones of occurrence of dangerous objects, protection of cultural heritage, flora and fauna with the use of shipping. It should be correlated with the study of spatial development for coastal areas and include provisions binding for the provincial governments, and through the provincial plan, also selected municipalities connected with the area covered by the plan, mainly regarding technical infrastructure.

\subsection{Land-Use Plans at the Provincial and Municipal Levels}

The Polish part of the Baltic Sea includes three provinces (Figure 6): West Pomerania, Pomerania, as well as Warmia and Mazury. The latter one is bordered only with the internal waters of the Vistula Lagoon. 


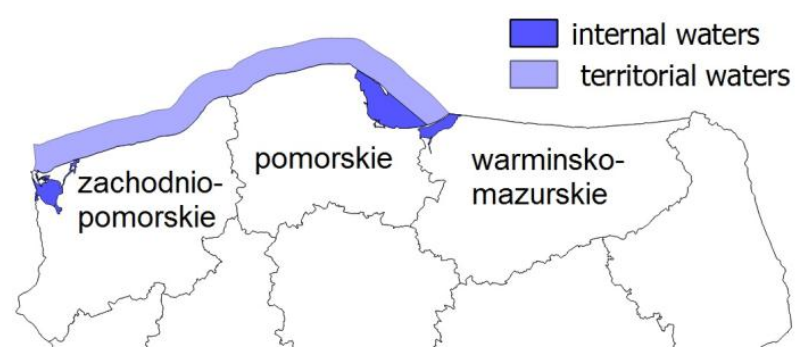

Figure 6. Provinces at the Baltic Sea. Source: prepared by the author based on State Register of Borders.

For each of these provinces there are land use plans drawn up, taking into consideration [24]:

- basic elements of the province settlement network and their communication and infrastructure links, including directions of cross-border connections,

- $\quad$ system of protected areas, including areas of environmental protection, protection of nature and cultural landscape, protection of spas and of cultural heritage, monuments and contemporary cultural assets,

- location of public purpose investments of supra-local significance,

- boundaries and principles of managing functional areas of supra-regional significance and, depending on the needs, boundaries and principles of managing functional areas of regional significance,

- special flood hazard areas,

- boundaries of closed areas and their buffer zones,

- $\quad$ areas with documented mineral deposits and documented complexes of carbon dioxide storage.

At the municipal level, local land use plans are drawn up, i.e., legal provisions adopted by the municipality councils in the form of a plan drawing and a text, which presents the future considerations of the area. They form the grounds for any investment undertakings [2]. They take into account a variety of issues, and their preparation is preceded by performing of a number of analyses, including a study of conditions and directions of spatial development. Due to the fact that there is no obligation to draw up local plans, only approximately $17 \%$ of the area of the three Baltic provinces is covered by them (Table 5 and Figure 7). In this case, the majority of investment plans are carried out on the basis of a zoning permit, which does not have to be compatible with any planning document which is higher in the hierarchy.

Table 5. Local land use plans in the provinces. Source: own study based on [55].

\begin{tabular}{cccc}
\hline Province & $\begin{array}{c}\text { Area of Land Use Plans } \\
\text { (ha) }\end{array}$ & $\begin{array}{c}\text { Area of Province } \\
\text { (ha) }\end{array}$ & $\begin{array}{c}\text { Land Use Plans in Province } \\
\text { (\%) }\end{array}$ \\
\hline warminsko-mazurskie & 310,942 & $2,417,347$ & 12.9 \\
pomorskie & 369,051 & $1,831,034$ & 20.2 \\
zachodniopomorskie & 437,880 & $2,289,248$ & 19.1 \\
\hline
\end{tabular}

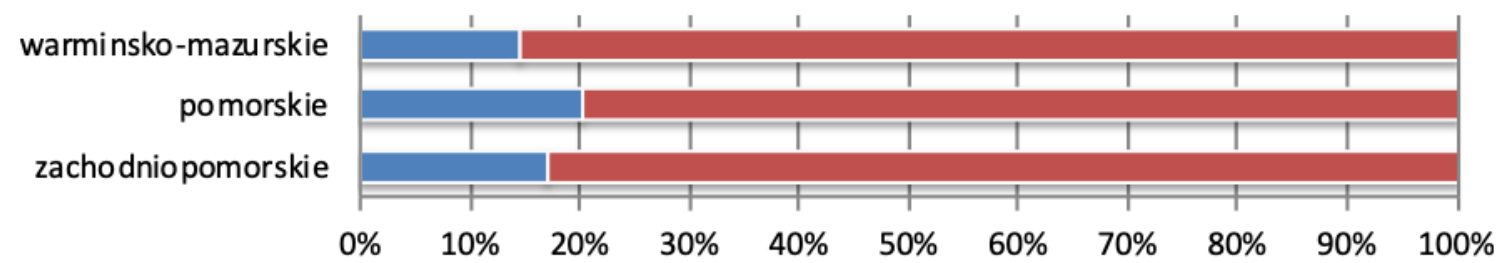

Figure 7. Local land use plans in the provinces. Source: own study based on [55].

Due to the small coverage of the region with the local plans, it was decided to verify what it looks like in each individual municipality (Figure 8). 


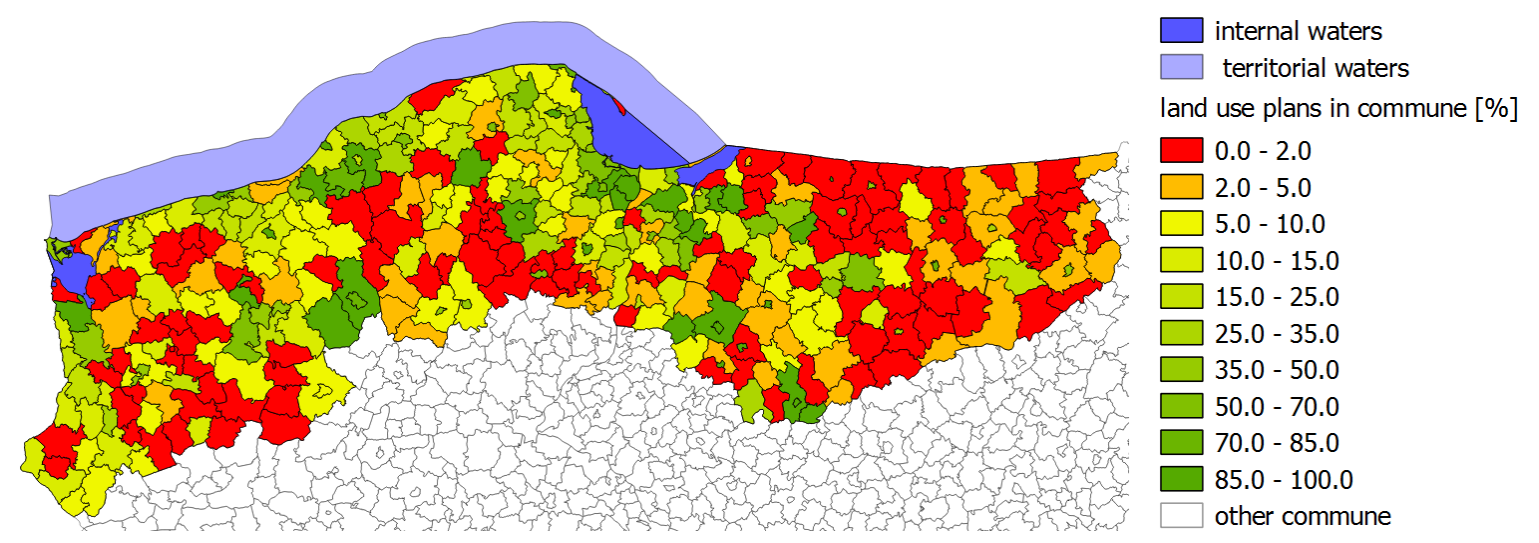

Figure 8. Local land use plans in the municipalities. Source: prepared by the author based on State Register of Borders and [55].

As depicted in Figure 8, coastal municipalities adopt local land use plans the most frequently, but the area of the municipalities which they cover is not large. The seafront is dominated by the municipalities which have adopted plans for at least over ten per cent of their surface. Larger touristic cities, such as Kołobrzeg or Puck, try to have resolutions adopted for the entire administrative area. Unfortunately, there are those municipalities where there are no plans at all, or which were drawn up for small areas only.

\subsection{Adjustment of the Polish Legislation to the EU Legislation}

Poland responded quickly to the necessity of transposition of the Directive establishing a framework for Maritime Spatial Planning. The bill, which would adjust the Polish law to the EU law was already created in the first quarter of 2015. The changes were introduced mainly in the act on the maritime areas of the Republic of Poland and Maritime Administration. The EU Directive didn't require any modifications in the provisions relating to spatial planning on land areas.

The baseline is defined more precisely in the Regulation [56], to which the delegation is included in the amended Act on maritime areas. This was due to the fact that all the Baltic countries, with the exception of the Republic of Poland, had a clearly defined course of the baseline using geodetic coordinates.

The waters situated between the coastline and the baseline of the territorial sea, unclassified before 2015, are classified to the internal waters. This led to the determination of the coastline in accordance with [57], as described in [58,59]. As the coastline is subjected to erosion and varies with time, it is off the map in many areas. However, since the area contiguous too it was not subjected to the Water Law, the coastline could not be established in accordance with its provisions.

The outer boundary of the territorial sea is a broken line parallel to the baseline, distanced by about 12 nautical miles from the baseline (Figure 9b), and not, as it was earlier, by 12 nautical miles at every point (Figure 9a). Its course is also specified in the regulation [31].

a)

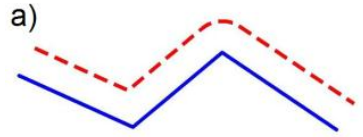

b)

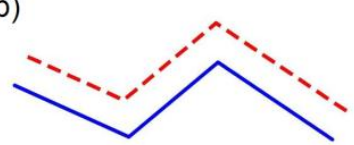

Figure 9. Changing the definition of the boundary. (a) Boundary as a broken line parallel to the baseline, distanced by 12 nautical miles at every point; (b) Boundary as a broken line parallel to the baseline, distanced by about 12 nautical miles from the baseline. Source: based on [31].

On the maritime areas of the Republic of Poland, a maritime zone it is established, contiguous to the territorial sea. This zone is a belt with a width of 12 nautical miles with the outer boundary as a broken line, specified in the regulation, parallel to the baseline, 24 nautical miles from that line. 
The Act on maritime areas clarifies the procedures for the authorization of the location of artificial islands, devices and structures in the Polish maritime areas, permits for the laying and maintenance of submarine cables and pipelines in the Polish maritime areas, and the planning procedure for maritime areas has been improved as well. In the future, several different land use plans for internal waters, territorial sea and exclusive economic zones are to be drawn up. In addition, it contains settlements on the areas and conditions for fishery and aquaculture, as well as for generating renewable energy.

The draft plan is drawn up by appropriate territorial managing director of a maritime office. However, it was compulsory to use an ecosystem approach in the process, and take into account:

- economic, social and environmental aspects,

- support of sustainable development and growth in the maritime sector,

- co-existence of relevant activities and uses of the sea.

From the delegation to the regulation concerning the required scope of the plans, it appears that its graphic part will be implemented in the form of databases.

Maritime administrative authorities are able to conduct analysis and studies, develop concepts and programs in order to draw up a plan, and also cooperate with coastal municipalities to ensure consistency of the plan with land use plans for land areas.

The plan includes provisions binding on provincial governments and municipalities, with internal marine waters, or municipalities neighboring the area of the plan by the shoreline, or by the boundaries of maritime areas equivalent of this line during the preparation of spatial development plans for provinces, studies of conditions and directions of spatial development of municipalities and local spatial development plans and urban planning provisions, respectively, in the following areas:

- location of public purpose investments of national significance, contained in the medium-term national development strategy and other development strategies, national spatial development concept and programs of government tasks,

- protected areas, including areas of protected space,

- manner of use of maritime areas, including the restrictions and approvals.

After the commencement of the work aimed to draw up a plan, the managing director of a maritime office shall make information about the possibility to submit comments and remarks on the plan public (over a period not shorter than 60 days) and shall notify in writing institutions and authorities competent to settle and review the draft plan. The director also addresses the General Director of Environmental Protection and the Chief Sanitary Inspector to agree on the scope and level of detail required for the Environmental Impact Assessment of the draft plan.

The draft plan is drawn up taking into account the above conclusions and settlements, and the alternative arrangement of the selected projects. Then, the environmental impact assessment of the plan is prepared. The draft plan is laid open for public inspection, and submitted for a review by:

- the provincial conservator,

- the director of the regional water management board,

- the minister of health,

- the competent mining supervisory authority,

- the competent authorities for the strategic environmental impact assessment,

- the director of the regional water management board.

It is also agreed with:

- commune heads, mayors or presidents of the cities located in the immediate vicinity of the project area,

- the regional conservation director, 
- the Minister of National Defense and the ministers of: economy, fisheries, environment, water management, internal affairs, tourism, communications, transportation, culture and national heritage protection,

- the Marshal,

- the director of the national park.

These authorities, within its functional and territorial competence, are obliged to cooperate in drawing up the plan by reviewing, submitting proposals and sharing information, no later than 45 days from the date of making the draft plan laid open for public inspection, together with the environmental impact assessment. The managing director of a maritime office may approve the draft plan as agreed if the authorities specified above have not declared any proposals or remarks within the prescribed period of 45 days.

Having considered all remarks, proposals and reviews of the draft plan, modifications are introduced, and the project is once again agreed upon in the necessary extent. The draft plan is presented to the minister of regional development in order to assess its compliance with the objectives and directions set out in the long-term national development strategy, settlements of the medium-term national development strategy, and other development strategies, national spatial development concept and programs of government tasks.

In the case of identifying the possibility of a significant transboundary environmental impact as a result of the implementation of the planned settlements, the managing director of a maritime office informs the General Director of Environmental Protection about such a possibility, and then provides him/her with a draft plan with an environmental impact assessment. After carrying out the proceedings regarding the transboundary environmental impact, the director of a maritime office again applies for the reviews and settlements with reference to the modifications to the draft plan.

A completed draft plan is presented to the minister of maritime economy for its adoption.

If, after the presentation of the draft plan, any modifications are made, the minister, having considered the remarks and proposals, may refer the draft plan to the competent regional director of a maritime office to resume activities necessary to introduce these modifications. The resumed activities include only the part of the draft plan subjected to the modification.

If, as a result of amendments to the specific provisions, a necessity arises to amend the plan, the update procedure should begin no later than six months from entry into force of the amended special provision. In addition, the land use plan for maritime areas will be subject to periodic assessment, at least once every 10 years.

\section{Results and Discussion}

The factors of the analysis have been selected based on a detailed study of the Polish spatial planning system, of both sea and land areas. The current conditions of the procedure have been considered to be Strengths (S) and Weaknesses (W), and the expected future phenomena that may affect the assessed procedure to be Opportunities (O) and Threats (T).

Table 6 summarizes the resulting internal and external factors that can have a positive or negative impact on the development of maritime areas (Table 6).

The weights used in the analysis were determined based on a questionnaire survey carried out among five spatial planning experts. The applied expert method can be classified as the Delphi method implemented in one iteration. The decision not to repeat the questionnaire was made due to the fact that the experts agreed in their opinions.

The surveys contained sets of the factors of the analysis prepared by the authors (strengths, weaknesses, opportunities and threats). The respondents' task was to rank the presented factors from the most important to the least important ones. The respondents assessed the validity of a given factor using the five-point Tilgner scale [60]: 1 point-no impact of the factor; 2 points-low impact; 3 points-average impact; 4 points—significant impact; and 5 points-maximum impact. They could also add their own suggestions of factors. 
Table 6. Factors of the analysis. Source: own study.

\begin{tabular}{|c|c|c|c|c|c|}
\hline No. & Weight & Internal Factors & No. & Weight & External Factors \\
\hline- & 1.00 & Strengths (S) & - & 1.00 & Opportunities (O) \\
\hline S1 & 0.30 & $\begin{array}{l}\text { Quick commencement of the Directive } \\
\text { transposition }\end{array}$ & $\mathrm{O} 1$ & 0.30 & Attracting investors and tourists \\
\hline $\mathrm{S} 2$ & 0.20 & $\begin{array}{l}\text { Increasing the attractiveness of investments in } \\
\text { Polish maritime areas }\end{array}$ & $\mathrm{O} 2$ & 0.20 & $\begin{array}{l}\text { Funding from the } \\
\text { European Union }\end{array}$ \\
\hline S3 & 0.15 & Using the existing planning studies & $\mathrm{O} 3$ & 0.15 & $\begin{array}{l}\text { Using the experience of } \\
\text { other countries }\end{array}$ \\
\hline S4 & 0.15 & Hierarchical structure of spatial planning & $\mathrm{O} 4$ & 0.15 & $\begin{array}{l}\text { Involvement of international } \\
\text { organizations }\end{array}$ \\
\hline S5 & 0.10 & $\begin{array}{l}\text { Identifying parts of maritime areas intended for } \\
\text { various uses }\end{array}$ & O5 & 0.10 & Public consultations \\
\hline S6 & 0.10 & Digitization of the plans & $\mathrm{O} 6$ & 0.10 & $\begin{array}{l}\text { Growing importance of Polish } \\
\text { maritime areas }\end{array}$ \\
\hline- & 1.00 & Weaknesses (W) & - & 1.00 & Threats (T) \\
\hline W1 & 0.30 & $\begin{array}{l}\text { Reviewing the draft plan instead of cooperation in } \\
\text { its development }\end{array}$ & $\mathrm{T} 1$ & 0.25 & Long duration of the settlements \\
\hline W2 & 0.20 & $\begin{array}{l}\text { Low coverage with the plans in the municipalities } \\
\text { contiguous to maritime areas }\end{array}$ & $\mathrm{T} 2$ & 0.25 & $\begin{array}{l}\text { Current degradation of } \\
\text { maritime areas }\end{array}$ \\
\hline W3 & 0.15 & Necessity of geodetic definition of a baseline & T3 & 0.15 & $\begin{array}{l}\text { Outdated and deficient data for } \\
\text { the plan }\end{array}$ \\
\hline W4 & 0.15 & $\begin{array}{l}\text { No geodetic determination of the location of } \\
\text { coastlines }\end{array}$ & $\mathrm{T} 4$ & 0.15 & $\begin{array}{l}\text { Insufficient international } \\
\text { involvement }\end{array}$ \\
\hline W5 & 0.10 & $\begin{array}{l}\text { Locating investments in maritime areas without } \\
\text { a plan }\end{array}$ & T5 & 0.10 & Obsolescence of the plan \\
\hline W6 & 0.10 & Prohibition to erect and use wind power stations & $\mathrm{T} 6$ & 0.10 & $\begin{array}{l}\text { Small scale of the plan could } \\
\text { result in a breach }\end{array}$ \\
\hline
\end{tabular}

The weights $\left(W_{i}\right)$ have been determined by converting the results from the surveys using Formula (1).

$$
w_{i}=\frac{p_{i}}{\sum p_{i}}
$$

where $p_{i}$ represents the arithmetic mean of the values assigned by the respondents to the $i$-th factor. The values obtained in this way have been rounded up to $5 \%$.

The authors have decided that such a small number of respondents has been sufficient because the Delphi method does not require the expert group to be a representative sample for statistical purposes [61]. In addition, there is very little empirical evidence about the influence of the number of respondents on the results of the Delphi method. That is why their reliability is assessed based on the characteristics of the experts.

The strengths of maritime spatial planning were identified as follows:

- Quick reaction of state administrative bodies to the Directive establishing a framework for Maritime Spatial Planning, which entered into force. Draft amendment to the national regulations relating to the planning of maritime areas in order to transpose EU legislation was created in the first quarter of 2015, which is less than six months after publication of the Directive.

- Increasing the attractiveness of investing in Polish maritime areas, which in turn will translate into a more dynamic development of the maritime economy and will intensify employment in the maritime sector.

- Ability to use the existing planning documents to develop land use plans for maritime spatial planning based on the implemented Directive establishing a framework for maritime spatial planning. 
- The hierarchical structure of spatial planning in Poland, the consequence of which is a strong connection between all planning documents created by public administration. As a result, documents created at lower levels than plan for maritime areas may assist in decision-making processes, taking place with its participation.

- Identification of the areas intended for selected forms of activity, which will enable carrying out of the process of maritime spatial planning in a sustainable manner, consistent with the long-term, economic and social interests of the state.

- Digitization of development plans for maritime areas, which will facilitate their accessibility and their use. It will also accelerate public consultations and opinion-forming process.

Weaknesses include:

- Reviewing the draft plan after it has been drawn up, instead of cooperation in its preparation process, on the side of the specialists from various fields. It is much more difficult to produce opinion on the finished material.

- Low coverage with the plans in the municipalities contiguous to maritime areas. These municipalities should take an active part in creating a plan for maritime areas, however, it is difficult to expect ant interaction if they do not have their own plans, which the maritime area should be consistent with.

- The necessity of geodetic definition of a baseline from which the boundaries of all maritime areas are determined.

- No geodetic determination of the location of coastlines, from which the areas that will be incorporated into internal waters are defined. These lines should be determined in accordance with the provisions of the Water Law, in the decisions of the managing directors of maritime offices, after determining them in the field.

- Locating investments in maritime areas in other ways than through plans. The use of artificial islands, engineering devices and structures in Polish maritime areas, the laying and maintenance of submarine cables and pipelines in internal waters and territorial sea is carried out under licenses. If they were issued before the entry into force of the development plan for maritime areas, they might not have taken into account global factors taken into consideration in the plan.

- Prohibition to erect and use wind power stations in internal marine waters and territorial sea, which significantly reduces the possibility of using a renewable energy source, such as wind, in coastal areas.

The opportunities which are identified by the authors are as follows:

- The possibility to attract investors and tourists to the Polish maritime areas if, as a result of proper planning, they will develop and will become more and more attractive.

- The possibility of funding spatial planning and different types of investments from the European Union.

- International cooperation in the preparation of plans for maritime areas, which will offer the opportunity to use the experience of other countries.

- The possibility that international organizations might engage in the planning of maritime areas.

- Public consultations, as a result of which the planning of maritime areas can go in directions which were not considered by the entities implementing the draft plan.

- Growing importance of Polish maritime areas, as a result of proper spatial planning and appropriate investing.

In contrast, the threats are:

- The long duration of the settlements regarding the draft plan and probably long-lasting introduction of the amendments resulting from the reviews, a number of entities that affect the final shape of the development plans for maritime areas. 
- Current degradation of maritime areas, as a result of improper use of resources before the plans for maritime areas are drawn up.

- In accordance with [51] development plans for maritime areas are prepared based on planning materials and source data, which should be up to date. However, it is a documentation from various sources, which is not always up to date, although it should be. It may also happen that the team preparing a draft plan will get incomplete data which are needed to prepare it. Analysis of the source material that can be used for spatial planning was performed by [62].

- Although development plans for maritime areas should be coordinated with other countries, there is a risk that, for various reasons, they may not be sufficiently involved in the planning process.

- Obsolescence of the development plan for maritime areas as a result of natural and anthropogenic factors.

- The small scale of the plan, which may result in improper location of the areas for various uses. According to the authors, it might be particularly evident in small basins, such as the Baltic Sea.

The interrelationship between the factors presented above have been illustrated in Tables 7 and 8 . If, according to the authors, there is correlation-" 1 " was marked in the tables. In the absence of the relationship- “0" was marked.

Table 7 summarizes the answers to the following questions:

- Does the strength allow to use a given opportunity?

- Does the strength allow to eliminate a given threat?

- Does the weakness restricts the use of a given opportunity?

- Does the weakness intensify the risks specific to a given threat?

Table 7. SWOT analysis of interrelationships. Source: own study.

\begin{tabular}{ccccccccccccc}
\hline & O1 & O2 & O3 & O4 & O5 & O6 & T1 & T2 & T3 & T4 & T5 & T6 \\
\hline S1 & 1 & 1 & 0 & 0 & 1 & 1 & 1 & 0 & 0 & 0 & 0 & 0 \\
S2 & 1 & 1 & 0 & 0 & 0 & 1 & 0 & 0 & 0 & 1 & 0 & 0 \\
S3 & 0 & 0 & 0 & 0 & 0 & 0 & 1 & 0 & 1 & 0 & 0 & 0 \\
S4 & 0 & 0 & 0 & 1 & 1 & 0 & 0 & 0 & 1 & 0 & 1 & 1 \\
S5 & 1 & 1 & 0 & 0 & 1 & 1 & 0 & 1 & 0 & 0 & 0 & 0 \\
S6 & 1 & 1 & 0 & 0 & 1 & 0 & 1 & 0 & 0 & 0 & 0 & 1 \\
\hline W1 & 0 & 0 & 0 & 0 & 0 & 0 & 1 & 0 & 0 & 1 & 0 & 0 \\
W2 & 1 & 1 & 0 & 0 & 0 & 1 & 1 & 0 & 1 & 0 & 0 & 1 \\
W3 & 0 & 0 & 0 & 0 & 0 & 0 & 0 & 0 & 1 & 0 & 0 & 0 \\
W4 & 0 & 0 & 0 & 0 & 0 & 0 & 0 & 0 & 1 & 0 & 0 & 0 \\
W5 & 0 & 0 & 0 & 0 & 1 & 0 & 0 & 1 & 0 & 0 & 0 & 0 \\
W6 & 1 & 1 & 0 & 0 & 0 & 1 & 0 & 0 & 0 & 0 & 0 & 0 \\
\hline
\end{tabular}

Table 8 summarizes the answers to the following questions:

- Does the opportunity strengthen a given strength?

- Does the opportunity allow to eliminate a given weakness?

- Does the threat eliminate a given strength?

- Does the threat emphasize a given weakness? 
Table 8. TOWS analysis of interrelationships. Source: own study.

\begin{tabular}{ccccccccccccc}
\hline & S1 & S2 & S3 & S4 & S5 & S6 & W1 & W2 & W3 & W4 & W5 & W6 \\
\hline O1 & 0 & 1 & 1 & 0 & 0 & 0 & 0 & 0 & 0 & 0 & 0 & 0 \\
O2 & 0 & 1 & 0 & 0 & 0 & 1 & 0 & 0 & 0 & 0 & 0 & 0 \\
O3 & 1 & 1 & 1 & 1 & 1 & 1 & 0 & 0 & 1 & 1 & 0 & 0 \\
O4 & 1 & 1 & 1 & 0 & 1 & 1 & 0 & 0 & 0 & 0 & 0 & 0 \\
O5 & 0 & 1 & 0 & 0 & 1 & 0 & 0 & 0 & 0 & 0 & 0 & 0 \\
O6 & 0 & 1 & 0 & 0 & 0 & 0 & 0 & 1 & 1 & 0 & 0 & 0 \\
\hline T1 & 0 & 1 & 0 & 0 & 1 & 1 & 1 & 1 & 0 & 0 & 0 & 0 \\
T2 & 0 & 1 & 0 & 0 & 1 & 0 & 0 & 0 & 0 & 0 & 0 & 1 \\
T3 & 0 & 0 & 1 & 0 & 1 & 1 & 0 & 1 & 0 & 1 & 0 & 0 \\
T4 & 0 & 1 & 0 & 0 & 1 & 0 & 0 & 0 & 0 & 0 & 0 & 0 \\
T5 & 0 & 0 & 0 & 0 & 0 & 0 & 0 & 0 & 0 & 0 & 0 & 0 \\
T6 & 0 & 0 & 0 & 0 & 0 & 0 & 0 & 0 & 0 & 0 & 0 & 0 \\
\hline
\end{tabular}

The relations in the SWOT and TOWS analyses can form the basis for a strategic analysis based on the proper adjustment of internal resources to external possibilities. The values of interaction between the factors of the analysis allow to point out to one of the four strategies for the development of the maritime spatial planning system. With the assumed configuration of internal and external factors as well as with the determined values of the weights, there are the following policy options:

- the aggressive one, when strengths dominate among the internal factors, in connection with opportunities among the external factors,

- the competitive one, when weaknesses dominate among the internal factors, in connection with opportunities among the external factors,

- $\quad$ the conservative one, when strengths dominate among the internal factors, in connection with threats among the external factors,

- the defensive one, when weaknesses dominate among the internal factors, in connection with threats among the external factors.

Table 9 presents a summary of the SWOT/TOWS analysis, and results of the strategic analysis as well as the selection of the strategy itself, have been depicted in Table 10.

Table 9. Summary of the results of SWOT/TOWS analysis. Source: own study.

\begin{tabular}{|c|c|c|c|c|c|c|}
\hline \multirow[b]{2}{*}{ Combination } & \multicolumn{2}{|c|}{ Results of SWOT Analysis } & \multicolumn{2}{|c|}{ Results of TOWS Analysis } & \multicolumn{2}{|c|}{ Summary of SWOT/TOWS } \\
\hline & $\begin{array}{l}\text { The sum of } \\
\text { interactions }\end{array}$ & $\begin{array}{l}\text { The sum of } \\
\text { products }\end{array}$ & $\begin{array}{l}\text { The sum of } \\
\text { interactions }\end{array}$ & $\begin{array}{l}\text { The sum of } \\
\text { products }\end{array}$ & $\begin{array}{l}\text { The sum of } \\
\text { interactions }\end{array}$ & $\begin{array}{l}\text { The sum of } \\
\text { products }\end{array}$ \\
\hline $\begin{array}{c}\text { Strengths }(\mathrm{S}) / \\
\text { Opportunities (O) }\end{array}$ & 32 & 5.65 & 36 & 5.95 & 68 & 11.60 \\
\hline $\begin{array}{l}\text { Strengths }(\mathrm{S}) / \\
\text { Threats }(\mathrm{T})\end{array}$ & 20 & 3.30 & 20 & 3.35 & 40 & 6.65 \\
\hline $\begin{array}{l}\text { Weaknesses (W)/ } \\
\text { Opportunities (O) }\end{array}$ & 14 & 2.30 & 8 & 1.15 & 22 & 3.45 \\
\hline $\begin{array}{c}\text { Weaknesses }(\mathrm{W}) / \\
\text { Threats }(\mathrm{T})\end{array}$ & 16 & 1.90 & 10 & 2.00 & 26 & 3.90 \\
\hline
\end{tabular}


Table 10. Results of the strategic analysis and strategy selection. Source: own study.

\begin{tabular}{ccc}
\hline & Opportunities & Threats \\
\hline \multirow{3}{*}{ Strengths } & Aggressive strategy & Conservative strategy \\
\cline { 2 - 3 } & Number of interactions & Number of interactions \\
& 68 & 40 \\
& Weighted number of interactions & Weighted number of interactions \\
& 11.60 & 6.65 \\
\hline \multirow{2}{*}{ Weaknesses } & Competitive strategy & Defensive Strategy \\
\cline { 2 - 3 } & Number of interactions & Number of interactions \\
& 22 & 26 \\
& Weighted number of interactions & Weighted number of interactions \\
& 3.45 & 3.90 \\
\hline
\end{tabular}

An overall study of the interactions between the factors of the analysis has demonstrated that both in the case of SWOT as well as TOWS relationships, the greatest number of correlations occur between the positive internal factors and the positive external factors. Such dependencies result from the identification of the internal and external factors presented in this article. The current conditions of maritime spatial planning procedures have been identified as internal factors, while the indications of the external factors have been dictated by future phenomena associated with the implemented procedure of creating plans of maritime areas. For the distinguished configuration of factors, it can be stated that the strength of the spatial planning procedure in the form of increased attractiveness of investments in Polish maritime areas strongly corresponds with all the positive future effects of the implementation of the planning development procedure. On the other hand, the least interaction for both SWOT and TOWS relationships occurs for the configuration of the negative internal factors in connection with the positive external factors.

Similar conclusions can be drawn from the strategic analysis of the connections between the individual factors. Both the number of interactions as well as the weighted number of interactions reveal the dominance of positive internal factors in connection with positive external factors. These dependencies prove that maritime spatial planning should be conducted using the strengths of the procedure and the external opportunities. The opportunities of the dynamic development of maritime areas are perceived mainly in the EU subsidies for various types of investments and in the possibilities of attracting investors and tourists to Polish maritime areas. The strengths of the maritime spatial planning procedure result, inter alia, from the awareness that spatial development plans organize human activities in these areas to meet ecological, economic and social objectives. Thus, the European Union law was quickly transposed into national solutions, and the development of spatial plans for Polish maritime areas has begun. Strengths also include the national experience gained in the preparation of land use plans, which translates into maritime spatial planning in aspects such as the hierarchical planning structure, digitization of plans, or the use of the existing planning documents.

\section{Conclusions}

Planning and spatial development of maritime areas is an extremely difficult issue, uniformly regulated at the European Union level. For its proper implementation, it requires the cooperation of specialists in many fields who, in order to draw up development plans for maritime areas, must be provided with source materials and the procedure for their preparation. The article presents an analysis of the legal regulations, from which it is evident that:

1. Maritime areas, which are subject to spatial planning, comprises the territory between the coastline and the boundary of the exclusive economic zone. 
2. Maritime Spatial Planning should take into consideration planning documents drawn up for the land areas. The purpose of such a procedure is the widest possible identification of the interaction between sea and land.

3. Establishment of the EU legislation was preceded by a preparatory action. These were projects in which the pilot planning documentation was created for the maritime areas of the European Union. A part of the plans, which were created in this way, may be used in the drawing up of relevant documents.

4. Pursuant to the uniform law of the European Union, the Member States should develop spatial plans for maritime areas until 31 March 2021.

5. Despite distant deadlines, Poland commenced works on introducing amendments to the national legislation, and has a study of conditions of spatial development of the Polish maritime areas, together with spatial analyses, based on which the development plan for maritime areas will be drawn up.

6. The procedure planned for adoption in Poland is appropriate and should be continued, using strengths and external opportunities, as outlined in the publication. This conclusion results from the strategic analysis carried out as a result of the SWOT and TOWS analyses based on the factors identified by the authors and regarding the current conditions of the maritime spatial planning procedure as well as the factors dictated by future phenomena associated with the implemented procedure of developing plans of maritime areas. The opportunities of the dynamic development of maritime areas are perceived mainly in the EU subsidies for various types of investments and in the possibilities of attracting investors and tourists to Polish maritime areas. The strengths of the maritime spatial planning procedure also result from the awareness that spatial development plans organize human activities in these areas to meet ecological, economic and social objectives. Thus, the European Union law was quickly transposed into the national solutions and the development of the spatial plans for Polish maritime areas has begun. The strengths also include the national experience gained in the preparation of land use plans, which translates into maritime spatial planning in aspects such as the hierarchical planning structure, digitization of plans, or the use of the existing planning documents.

Author Contributions: Conceptualization, A.B.; Investigation, A.B. and T.A.; Methodology, A.B.; Supervision, P.P.; Visualization, A.B.; Writing—original draft, A.B. and T.A.; Writing—review \& editing, T.A. and P.P.

Funding: This work was financed by research funds from the AGH University of Science and Technology, No. 11.11.150.006.

Conflicts of Interest: The authors declare no conflict of interest.

\section{References}

1. Skrenty, Ż. Podstawowe Zasady Planowania Przestrzennego-Istota i Cele Ustanowienia. PWSZ IPiA Studia Lubuskie 2011, 7, 245-260. (In Polish)

2. Bieda, A.; Hanus, P.; Hycner, R. Geodezyjne Aspekty Planowania Przestrzennego i Wybranych Opracowań Projektowych; Wydawnictwo Gall: Katowice, Poland, 2012. (In Polish)

3. Bieda, A.; Parzych, P. Development of spatial politics of monumental towns based on Krakow example. In Proceedings of the International Multidisciplinary Scientific GeoConference SGEM: Geodesy and Mine Surveying, Photogrammetry and Remote Sensing, Albena, Bulgaria, 16-22 June 2013; Volume 2, pp. 143-150.

4. Telega, A.; Bieda, A. Analiza stopnia dopasowania sposobu użytkowania ziemi, jako narzędzie zarządzania konfliktami przestrzennymi (in Polish). Infrastruktura i Ekologia Terenów Wiejskich. 2015, 4, 1007-1020.

5. Janelle, D.G.; Millward, H.A. Locational conflict patterns and urban ecological structure. Tijdschrift voor Economische en Sociale Geografie. 1976, 67, 102-113. [CrossRef]

6. Dühr, S.; Stead, D.; Zonneveld, W. The Europeanization of spatial planning through territorial cooperation. Plan. Pract. Res. 2007, 22, 291-307. [CrossRef]

7. Rivolin, U.J. EU territorial governance: Learning from institutional progress. Eur. J. Spat. Dev. 2010, 38, 1-28. 
8. Backer, H. Transboundary maritime spatial planning: A Baltic Sea perspective. J. Coast. Conserv. 2011, 15, 279-289. [CrossRef]

9. Cieślak, A. Maritime spatial planning in the Baltic Sea Region. Informationen zur Raumentwicklung 2009, 8, 607-612.

10. Douvere, F. The importance of marine spatial planning in advancing ecosystem-based sea use management. Mar. Policy 2008, 32, 762-771. [CrossRef]

11. Trouillet, B.; Guineberteau, T.; De Cacqueray, M.; Rochette, J. Planning the sea: The French experience. Contribution to marine spatial planning perspectives. Mar. Policy 2011, 35, 324-334. [CrossRef]

12. Zaucha, J. (Ed.) Planowanie Przestrzenne Obszarów Morskich. Polskie Uwarunkowania i Plan Pilotażowy; Instytut Morski w Gdańsku: Gdańsk, Poland, 2009. (In Polish)

13. Zaucha, J. Sea basin maritime spatial planning: A case study of the Baltic Sea region and Poland. Mar. Policy 2014, 50, 34-45. [CrossRef]

14. Keijser, X.; Ripken, M.; Mayer, I.; Warmelink, H.; Abspoel, L.; Fairgrieve, R.; Paris, C. Stakeholder Engagement in Maritime Spatial Planning: The Efficacy of a Serious Game Approach. Water 2018, 10, 724. [CrossRef]

15. Jay, S.; Alves, F.L.; O’Mahony, C.; Gomez, M.; Rooney, A.; Almodovar, M.; Gee, K.; de Vivero, J.L.S.; Gonçalves, J.M.S.; Fernandes, M.L.; et al. Transboundary dimensions of marine spatial planning: Fostering inter-jurisdictional relations and governance. Mar. Policy 2016, 65, 85-96. [CrossRef]

16. Jean, S.; Gilbert, L.; Medema, W.; Keijser, X.; Mayer, I.; Inam, A.; Adamowski, J. Serious Games as Planning Support Systems: Learning from Playing Maritime Spatial Planning Challenge 2050. Water 2018, 10, 1786. [CrossRef]

17. Rivolin, U.J. Global crisis and the systems of spatial governance and planning: A European comparison. Eur. Plan. Stud. 2017, 25, 994-1012. [CrossRef]

18. Kwartnik-Pruc, A.; Przewięźlikowska, A. Porównanie funkcjonowania planowania przestrzennego w Polsce i w Niemczech. Geomat. Environ. Eng. 2007, 1, 149-160. (In Polish)

19. Topczewska, T. Integrated planning of development and revitalisation of cities in selected countries of the European union and in Poland. Człowiek i Środowisko. 2012, 36, 21-40.

20. Krajewska, M.; Źróbek, S.; Kovač, M.S. The Role of Spatial Planning in the Investment Process in Poland and Slovenia. Real Estate Manag. Valuat. 2014, 22, 52-66. [CrossRef]

21. Bieda, A.; Pukanská, K.; Sala, B. Spatial planning in localities with special historic values on examples of Poland and Slovakia. Geomat. Environ. Eng. 2018, 12, 5-27. [CrossRef]

22. DeSilets, L.D. SWOT is useful in your tool kit. J. Contin. Educ. Nurs. 2008, 39, 196-197. [CrossRef]

23. Albrechts, L. Strategic (spatial) planning reexamined. Environ. Plan. B Plan. Des. 2004, 31, 743-758. [CrossRef]

24. Agarwal, R.; Grassl, W.; Pahl, J. Meta-SWOT: Introducing a new strategic planning tool. J. Bus. Strategy 2012, 33, 12-21. [CrossRef]

25. Ghazinoory, S.; Abdi, M.; Azadegan-Mehr, M. SWOT methodology: A state-of-the-art review for the past, a framework for the future. J. Bus. Econ. Manag. 2011, 12, 24-48. [CrossRef]

26. Polat, Z.A.; Alkan, M.; Sürmeneli, H.G. Determining strategies for the cadastre 2034 vision using an AHP-Based SWOT analysis: A case study for the turkish cadastral and land administration system. Land Use Policy 2017, 67, 151-166. [CrossRef]

27. Dawidowicz, A.; Źróbek, R. Multipurpose water-marine cadastre in Poland-development directions. Acta Adriat. Int. J. Mar. Sci. 2014, 55, 127-144.

28. Dawidowicz, A.; Klimach, A.; Szpara, A. Management of Seaport Real Estate Stock in Relation: Port-Marine City. Geomat. Environ. Eng. 2017, 11, 35-50. [CrossRef]

29. Pawlikowska, E.; Popek, P.; Bieda, A.; Moteva, M.; Stoeva, A. Analysis of the Legal Methods of Agricultural Land Protection in Central Europe On the Example of Poland and Bulgaria. Real Estate Manag. Valuat. 2017, 25, 58-71. [CrossRef]

30. Bieda, A.; Brzozowska, A. Analiza SWOT/TOWS jako metoda określania kierunków rozwoju przestrzennego. Acta Sci. Polonorum Adm. Locorum 2017, 16, 151-160. [CrossRef]

31. Bieda, A.; Wójciak, E.; Parzych, P. Assessment of valuation methodology for land properties with mineral deposits used in Poland. Acta Montan. Slovaca 2018, 23, 184-193.

32. Sarsby, A. SWOT Analysis. 2016. Available online: www.lulu.com (accessed on 24 February 2019).

33. The Convention of 10 December 1982. The United Nations Convention on the Law of the Sea. Available online: www.un.org (accessed on 29 January 2019). 
34. Bugajski, D.R. Prawa Żeglugowe Okrętu w Świetle Prawa Międzynarodowego; Wydawnictwo Naukowe Scholar: Warszawa, Poland, 2009; p. 20. (In Polish)

35. The Directive of 23 October 2000. Directive 2000/60/EC of the European Parliament and of the Council Establishing a Framework for Community Action in the Field of Water Policy. Available online: eur-lex. europa.eu. (accessed on 29 January 2019).

36. The Directive of 17 June 2008. Directive 2008/56/EC EC of the European Parliament and of the Council Establishing a Framework for Community Action in the Field of Marine Environmental Policy (Marine Strategy Framework Directive). Available online: eur-lex.europa.eu. (accessed on 29 January 2019).

37. The Act of 21 March 1991. Marine areas of Polish Republic and Maritime Administration Law. Journal of Laws of 1991 No. 32, Item. 131, as Amended. Available online: www.isap.sejm.gov.pl (accessed on 29 January 2019). (In Polish)

38. Regulation of 29 April 2003. Determining the Minimum and Maximum Width of Technical Belt and Protective Belt and Method for Determination of Their Borders. Journal of Laws of 2003 No. 89, Item. 820, as Amended. Available online: www.isap.sejm.gov.pl (accessed on 29 January 2019). (In Polish)

39. The Act of 17 May 1989. Geodetic and Cartographic Law. Journal of Laws of 2000 No. 100, Item. 1086, as Amended. Available online: www.isap.sejm.gov.pl (accessed on 29 January 2019). (In Polish)

40. The Central Intelligence Agency. The World Factbook. Available online: www.cia.gov (accessed on 29 January 2019).

41. The Treaty of 7 February 1992. Consolidated Versions of the Treaty on European Union and the Treaty on the Functioning of the European Union (2010/C083/01). Available online: eur-lex.europa.eu. (accessed on 29 January 2019).

42. The Directive of 23 July 2014. Directive 2014/89/EU of the European Parliament and of the Council Establishing a Framework for Maritime Spatial Planning. Available online: eur-lex.europa.eu. (accessed on 29 January 2019).

43. European Commission. Maritime Affairs. European Atlas of the Seas. Available online: eu.europa.eu (accessed on 29 January 2019).

44. The Act of 27 March 2003. Planning and Spatial Development. Journal of Laws of 2003 No. 80, Item. 717, as Amended. Available online: www.isap.sejm.gov.pl (accessed on 29 January 2019). (In Polish)

45. The Act of 6 December 2006. Rules of Development Policy. Journal of Laws of 2009 No. 84, item. 712, as Amended. Available online: www.isap.sejm.gov.pl (accessed on 29 January 2019). (In Polish)

46. Cieślak, A.; Mostowiec, A. Planowanie przestrzenne polskich obszarów morskich 2014. Available online: www.ums.gov.pl (accessed on 29 January 2019). (In Polish)

47. COMMIN. The Baltic Spatial Conceptshare. Available online: commin.org (accessed on 29 January 2019).

48. European Spatial Planning Observation Network. Available online: www.espon.eu (accessed on 29 January 2019).

49. International Society of City and Regional Planners. Available online: isocarp.org (accessed on 29 January 2019).

50. Vision and Strategies around the Baltic Sea. Available online: www.vasab.org (accessed on 29 January 2019).

51. Regulation of 5 August 2013. The Land Use Plan for Maritime Areas. Journal of Laws of 2013 Item. 1051. Available online: www.isap.sejm.gov.pl (accessed on 29 January 2019). (In Polish)

52. The Act of 9 June 2011. Geological and Mining Law. Journal of Laws of 2011 No. 163, Item. 981, as Amended. Available online: www.isap.sejm.gov.pl (accessed on 29 January 2019). (In Polish)

53. The Study of February 2014. The Study of Conditions of Spatial Development of the Polish Maritime Areas. Available online: www.ums.gov.pl (accessed on 29 January 2019). (In Polish)

54. The Resolution of 13 December 2011. National Spatial Development Concept. Journal of Laws of 2012 item. 252. Available online: www.isap.sejm.gov.pl (accessed on 29 January 2019). (In Polish)

55. Statistics Poland. Regional Statistics. Available online: stat.gov.pl (accessed on 29 January 2019).

56. Regulation of 13 January 2017. On the Detailed Course of the Baseline, Outer Limit of the Territorial Sea and Outer Limit of the Contiguous Zone of the Republic of Poland. Journal of Laws of 2017 Item. 183. Available online: www.isap.sejm.gov.pl (accessed on 29 January 2019). (In Polish)

57. The Act of 20 July 2017. Water Law. Journal of Laws of 2017, Item. 1566. Available online: www.isap.sejm. gov.pl (accessed on 29 January 2019). (In Polish) 
58. Bieda, A.; Hanus, P.; Parzych, P. The problems of establishing cadastral boundaries in river erosion and accumulation area according to the polish law. In Proceedings of the FIG Working Week 2012, Rome, Italy, 6-10 May 2012.

59. Kwartnik-Pruc, A. Practical Problems of Delimitation of Real Estate under the Provisions of the Water Law. Geomat. Environ. Eng. 2014, 8, 93-106. [CrossRef]

60. Babbie, E. Podstawy Badań Społecznych; Polskie Wydawnictwo Naukowe: Warszawa, Poland, 2008. (In Poland)

61. Powell, C. The Delphi technique: Myths and realities. J. Adv. Nurs. 2003, 41, 376-382. [CrossRef]

62. Kocur-Bera, K.; Dudzińska, D. Information and database range used for maritime spatial planning and for integrated management of the coastal zone-Case study in Poland, Baltic Sea. Acta Adriat. 2014, 55, 179-194.

2019 by the authors. Licensee MDPI, Basel, Switzerland. This article is an open access article distributed under the terms and conditions of the Creative Commons Attribution (CC BY) license (http://creativecommons.org/licenses/by/4.0/). 